\title{
Cadmium Content and Accumulation in Lettuce Grown on Different Types of Soil
}

\author{
LJ ILJ ANA BOSKOVIC-RAKOCEVIC ${ }^{1 *}$, RADOS PAVLOVIC ${ }^{2}$, MILENA DURIC ${ }^{1}$, MILAN PAVLOVIC ${ }^{3}$ \\ 'University of Kragujevac, Faculty of Agronomy, Department of Soil and Mechanisation, Cara Dusana 34, 32000 Cacak, Serbia \\ University of Kragujevac, Faculty of Agronomy, Department of Field and Vegetable Crops, Cara Dusana 34, 32000 Cacak, Serbia \\ 3University Business Academy in Novi Sad, Cvecarska 2, 21000 Novi Sad, Serbia
}

\begin{abstract}
This study was conducted on a pseudogley (pH 5.0) and a vertisol (pH 6.9) to analyze their total and available $\mathrm{Cd}$ levels and $\mathrm{Cd}$ accumulation by lettuce for risk assessment of potential human health impacts. Total $\mathrm{Cd}$ levels in both soil types were below maximum allowable concentrations, and showed a high dependence on soil $\mathrm{pH}(R=-0.974)$. Monoammonium phosphate (MAP) fertilizers containing various amounts of cadmium led to an increase in cadmium uptake, with higher concentrations accumulated in lettuce roots than in leaves. The transfer factor showed that $C d$ uptake from the pseudogley was much higher than from the vertisol, and its values indicated that lettuce is a cadmium hyperaccumulator. Lettuce head weight decreased with increasing cadmium rates and was highly negatively correlated with $C d$ concentration in the leaves $(R=-0.818)$.
\end{abstract}

Keywords: cadmium, monoammonium phosphate, lettuce, transfer factor

Vegetable production necessitates much higher fertilization rates compared to the production of other agricultural crops, thus causing danger of accumulation of deleterious elements found in fertilizers. In lettuce ( Lactuca sativa L.) as a leafy vegetable crop used fresh and characterized by a short growing season and intense growth, there is the highest risk of uptake of these elements [1].

The presence of high $\mathrm{Cd}$ concentrations in mineral fertilizers, phosphorus ones in particular, is a serious problem due to $\mathrm{Cd}$ toxicity and availability to plants $[2,3]$. Its content is $3.4-232 \mathrm{mg} / \mathrm{kg}$ in phosphorus fertilizers [4], $2.08-7.50 \mathrm{mg} / \mathrm{kg}$ in superphosphate [5], and $144 \mathrm{mg} / \mathrm{kg}$ in MAP [6].

There are different opinions in the literature regarding the effect of phosphorus fertilizers on Cd availability in soils. Many authors have reported an increase in $\mathrm{Cd}$ content in soils as affected by the use of phosphorus fertilizers containing $\mathrm{Cd}[3,7,7]$. Other authors found no significant difference in soil $\mathrm{Cd}$ levels after phosphorus fertilizer treatment $[8,9]$. Cd availability in soils is substantially affected by soil type $[2,10,11]$, primarily $\mathrm{pH}$ and organic matter content $[12,13]$.

Generally, the uptake of $\mathrm{Cd}$ by plants is closely related to its concentration in soils. Cadmium concentration in vegetable crops increases with increasing $\mathrm{Cd}$ concentration in the soil [14, 15, 3]. Most commonly, the increase in $\mathrm{Cd}$ levels in edible plant parts causes no toxicity symptoms, but can have deleterious effects on human health [16], and adverse effects on crop yield [17, 18]. Significantly higher amounts of $\mathrm{Cd}$ accumulate in roots than in aboveground portions $[6,18,19]$.
Potential human exposure to toxic effects of soil $\mathrm{Cd}$ through the food chain is best indicated by the transfer factor defined as the ratio of total $\mathrm{Cd}$ concentration in the soil to that in the plant $[2,20]$.

The objective of this study was to determine the effect of monoammonium phosphate containing different amounts of cadmium on $\mathrm{Cd}$ content in two soil types, $\mathrm{Cd}$ availability to plants and potential soil pollution with this metal.

\section{Experimental part}

Plant material and field trial

The experiment was conducted in pots under greenhouse conditions at the trial field of the Faculty of Agronomy at Trbušani near Ėaeak, Western Serbia ( $43^{\circ} 55^{\prime} \mathrm{N}$, latitude; $20^{\circ} 19^{\prime} \mathrm{E}$ longitude; $255 \mathrm{~m}$ a.s.l.) (fig. 1).

The research involved two soil types, a pseudogley and a vertisol (table 1). Each pot was filled with $5 \mathrm{~kg}$ air-dry soil sampled from a 0-30 cm layer and sieved through a $4 \mathrm{~mm}$ sieve. Then, one young lettuce cv. 'Sun Star' plant was planted per container. During planting, the plants were watered until field moisture capacity was reached, with subsequent watering treatments employed at a soil moisture below $70 \%$ of the field capacity.

The experimentinvolved mineral fertilization with two MAP (monoammonium phosphate- $11 \% \mathrm{~N}, 52 \% \mathrm{P}_{2} \mathrm{O}_{5}$ ) products, one manufactured in Serbia (MAP-S), the other in Russia (MAPR). The content of Cd in MAP-Sand MAP-R fertilizers was 12.32 $\mathrm{mg} / \mathrm{kg}$ and $0.34 \mathrm{mg} / \mathrm{kg}$, respectively. In order to improve the fertility of the soils used for lettuce production, nitrogen $(0.15$ $\mathrm{g} / \mathrm{kg}$ soil) as CAN (calcium ammonium nitrate, containing $27 \%$ of $\mathrm{N}_{\text {TOT }}$ ), and potassium ( $0.1 \mathrm{~g} / \mathrm{kg}$ soil) as $\mathrm{KCl}$ (potassium

Table 1

CHEMICAL PROPERTIES OF SOILS

\begin{tabular}{|l|c|c|c|c|c|c|}
\hline Type of soil & $\mathrm{pH} / \mathrm{H}_{2} \mathrm{O}$ & $\begin{array}{c}\text { Humus } \\
(\%)\end{array}$ & $\begin{array}{c}\text { Available P } \\
(\mathrm{mg} / \mathrm{kg})\end{array}$ & $\begin{array}{c}\text { Available K } \\
(\mathrm{mg} / \mathrm{kg})\end{array}$ & $\begin{array}{c}\text { Total Cd } \\
\text { concentration } \\
(\mathrm{mg} / \mathrm{kg})\end{array}$ & $\begin{array}{c}\text { Available Cd } \\
\text { concentration } \\
(\mathrm{mg} / \mathrm{kg})\end{array}$ \\
\hline $\begin{array}{l}\text { Pseudogley } \\
\text { Vertisol }\end{array}$ & 5.0 & 2.52 & 86 & 174 & 0.34 & 0.12 \\
\hline
\end{tabular}

\footnotetext{
* email: ljiljabr@kg.ac.rs
} 


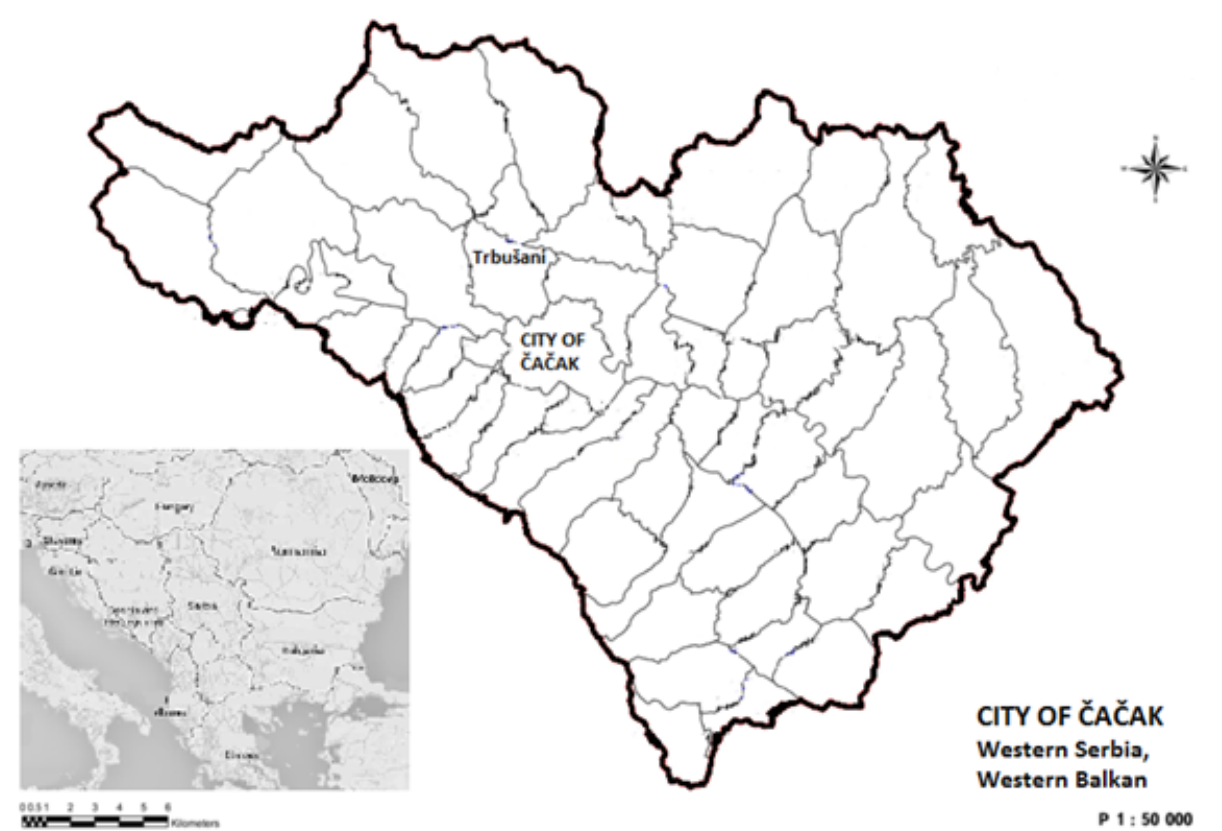

Fig. 1 Map of Cacak with sampling location

chloride, containing $60 \%$ of $\mathrm{K}_{2} \mathrm{O}$ ) were incorporated into the soils.

The experiment consisted of an untreated control and four treatments in three replications: 1 . Control -withoutCd; 2 . MAP$\mathrm{S}-15 \mathrm{mg} / \mathrm{kg}$ soil; 3. MAP-S -30 mg/kg soil; 4. MAP-R - $15 \mathrm{mg} /$ $\mathrm{kg}$ soil; 5 . MAP-R $-30 \mathrm{mg} / \mathrm{kg}$ soil.

\section{Sample collection and preparation}

Soil and plant material samples were collected for analysis at the end of the lettuce growing season. Soil samples were air-dried, ground and sieved through a $<2 \mathrm{~mm}$ stainless steel sieve. All plantsampleswere separated into edible and inedible parts, and then stored in polyethylene bags in the field and transferred to the laboratory. In the laboratory, the samples were carefully washed with tap water and then with deionized water to remove soil and dust particles. Then, they were weighed, dried at $65^{\circ} \mathrm{C}$ for $72 \mathrm{~h}$, reweighed, ground and stored in plastic bottles for chemical analysis.

\section{Soil and plant chemical analysis}

Soil samples were analyzed using standard methods: the soil pH was measured at a 1:2.5 ratio of soil to distilled water, using a pH meter; the humus content was determined by oxidation with $\mathrm{KMnO}_{4}$ solution (according to Kotzman); available phosphorus and potassiumextraction with $0.1 \mathrm{M} \mathrm{NH}$-lactate and $0.4 \mathrm{M} \mathrm{CH}_{3} \mathrm{COOH}$, according to Egner-Riehm ( $\mathrm{P}$ was analyzed spectrophotometrically; K was determined by flame photometry.

Total $\mathrm{Cd}$ content in soil was determined by the aqua regia ( $\left.\mathrm{HCl} / \mathrm{HNO}_{3}, 3 / 1\right)$ extraction method described in [21]. Available $\mathrm{Cd}$ content in soil was determined by extraction with $0.005 \mathrm{M}$ DTPA $+0.01 \mathrm{M} \mathrm{CaCl}_{2}+0.1 \mathrm{M}$ TEA solution, $p H=7.3$ [22].

$\mathrm{Cd}$ concentration in lettuce was determined by digestion with $\mathrm{HNO}_{3} / \mathrm{HClO}_{4}, 5 / 1$, described in [23]. Cd concentration was determined bythe atomic absorption spectrophotometer Perkin-Elmer 3300/96, model MHS-10 (Perkin-Elmer, Santa Clara, California, USA).

\section{Data analysis}

Results were subjected to analysis of variance (ANOVA), and statistical significance of differences was determined by the LSD-test $(P<0.05)$, (Michigan State University, East Lansing, MI, USA).

\section{Transfer factor}

In order to evaluate the ratio of heavy metal concentration in plants to that in soil, the transfer factor (TF) for the heavy metal was computed based on the method described by [24], according to the formula

$$
T F=\frac{P_{s}}{S_{t}}
$$

where: $P_{c}$ - heavy metal concentration in plant $(\mathrm{mg} / \mathrm{kg}$, dry weight); $\mathcal{S}_{t}$ - total metal concentration in the soil in which the plant was grown $(\mathrm{mg} / \mathrm{kg})$.

\section{Results and discussions \\ Cd concentrations in soils}

Total Cd concentration before trial establishmentwas 0.34 $\mathrm{mg} / \mathrm{kg}$ in the pseudogley and $0.08 \mathrm{mg} / \mathrm{kg}$ in the vertisol, whereas available Cd concentration was $0.12 \mathrm{mg} / \mathrm{kg}$ and 0.05 $\mathrm{mg} / \mathrm{kg}$, respectively (table 1 ). The differences in total and available cadmium levels were expected, given the different properties of the two soil types. The pseudogley is acid in reaction, with a poor supply of humus and a moderate supply of available phosphorus and potassium. The vertisol is neutral in reaction and well supplied with humus and available phosphorus and potassium.

$\mathrm{Cd}$ dynamics in the soil is dependent on a number of parameters ( $p \mathrm{H}$, clay content, organic matter content), which may lead to poor $\mathrm{Cd}$ mobility in the soil and decreased adsorption by the plant. Nevertheless, the highest effect on $\mathrm{Cd}$ concentration in the soil is exhibited by $\mathrm{pH}$, as $\mathrm{pH}$ can modify the transfer of elements from the bonded phase to the soil solution $[25,11]$. In this study, the acid reaction of the pseudogley ( $p \mathrm{H}$ 5.0) resulted in increased $\mathrm{Cd}$ concentration, while in the vertisol $(\mathrm{pH} 6.9) \mathrm{Cd}$ mobility decreased, due to the deposition of hydroxides and oxides or due to the formation of insoluble organic compounds [26]. The relationship between soil $\mathrm{pH}$ and total $\mathrm{Cd}$ concentration in the soils is presented in figure 2 and shows a significant negative correlation $(R=-0.974)$.

Overall, the analysis of total average $C d$ concentration in the soil shows no contamination of these soils with cadmium, since total Cd concentration was below maximum allowable concentration $(2 \mathrm{mg} / \mathrm{kg}$ ), i.e. 0.159 $\mathrm{mg} / \mathrm{kg}$ in the pseudogley and $0.053 \mathrm{mg} / \mathrm{kg}$ in the vertisol (table 2). Potential toxicity of heavy metals is more related to their available concentrations than to their total 


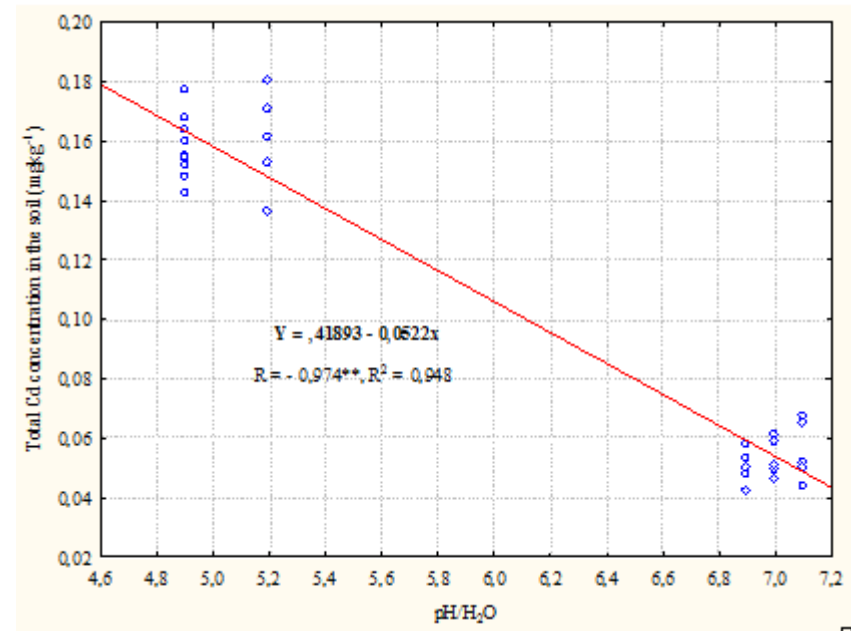

Fig. 2 Relationships between $\mathrm{pH} / \mathrm{H}_{2} \mathrm{O}$ and total $\mathrm{Cd}$ concentration in the soil

Table 2

TOTAL AND AVAILABLE Cd CONCENTRATION IN THE SOIL, Cd CONCENTRATION IN THE ROOT AND LEAF OF LETTUCE AND LETTUCE HEAD WEIGHT

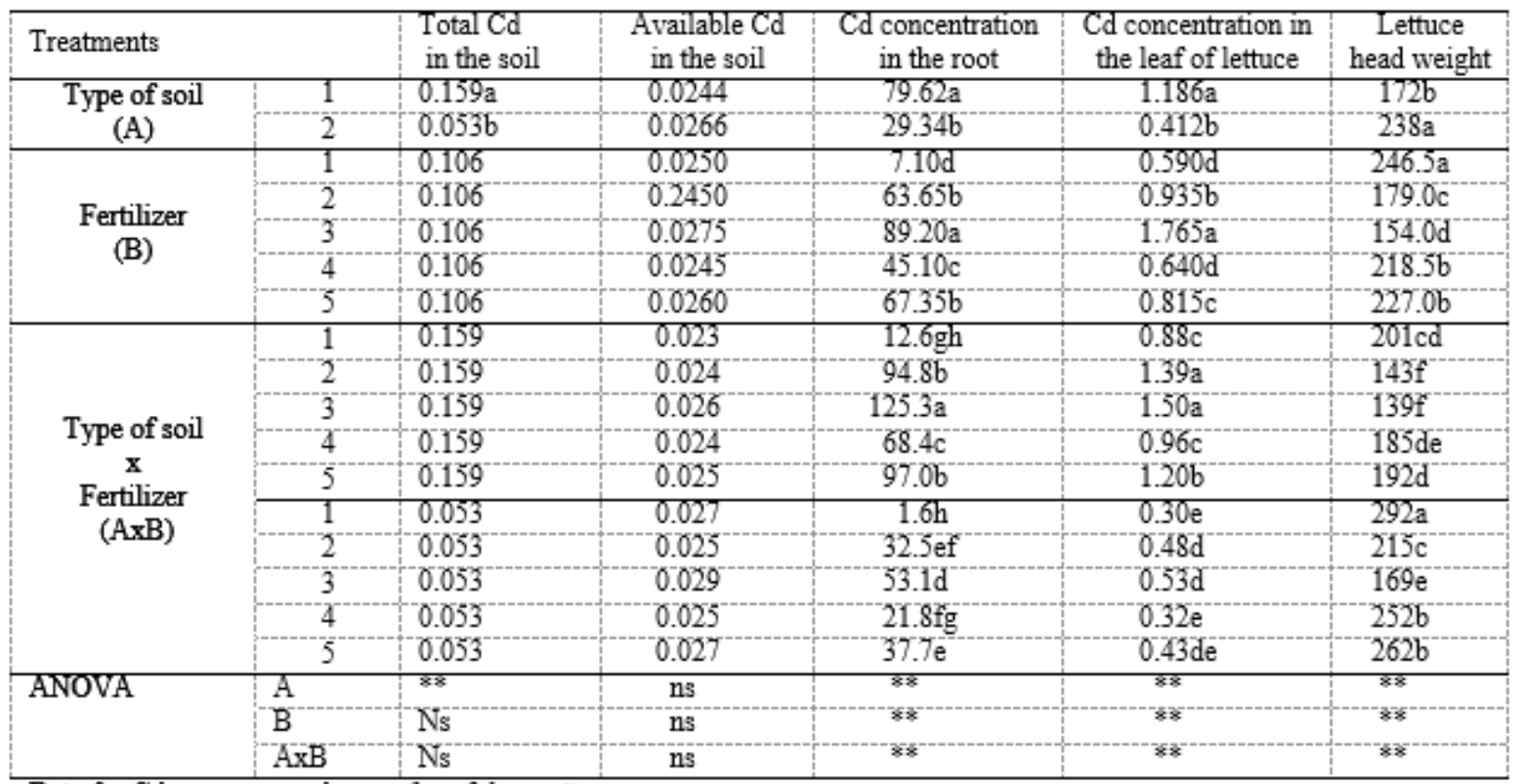

Data for Cd are expressed as $\mathrm{mg} / \mathrm{kg}$ of dry matter.

Data for lettuce head weight are expressed as $\mathrm{g}$.

The same letters in columns indicate non-significant differences between means at $P \leq 0.05$ by LSD test.

ns: non significant

concentration in the soil [27, 28]. In this study, before trial establishment, available $\mathrm{Cd}$ level in the pseudogley and vertisol was $0.12 \mathrm{mg} / \mathrm{kg}$, and $0.05 \mathrm{mg} / \mathrm{kg}$, respectively. After the lettuce growing cycle, available Cd concentration in both soil types decreased and exhibited a slight variation, with no statistical significance, both between soil types and between treatments with MAP from different sources and its application rates.

These findings indicate increased $\mathrm{Cd}$ mobility in the pseudogley, primarily due to the acid soil reaction and low organic matter content, resulting in increased uptake by the lettuce plant and increased accumulation in the leaves (table 2) compared to the plants grown on the vertisol, and hence the available $\mathrm{Cd}$ concentration in the pseudogley was lower than in the vertisol. Similar findings were reported by [9] who studied the effect of increasing rates of phosphorus fertilizers and obtained an average available cadmium concentration of $0.23 \mathrm{mg} / \mathrm{kg}$. As for the percent contribution of DTPA-Cd to the total soil concentration (table 3), \%DTPA-Cd ranged from 47.2 to $54.7 \%$ in the vertisol, and from 14.5 to $16.4 \%$ in the pseudogley. Similar results on clay soils were obtained by [4] and [29] who determined that DTPA-Cd accounted for 14.5$83.3 \%$ and about $38 \%$, respectively, of the total $\mathrm{Cd}$ concentration.

\section{Cd concentration in lettuce}

$\mathrm{Cd}$ concentration in plant tissues normally ranges from 0.05 to $0.2 \mathrm{mg} / \mathrm{kg}$ dry matter [30], with more $\mathrm{Cd}$ accumulated in the root than in aboveground plant parts $[6,19,31]$.

In this study (table 2), Cd concentration in the root of lettuce grown on the pseudogley was between $12.6 \mathrm{mg} / \mathrm{kg}$ (control) and $125.3 \mathrm{mg} / \mathrm{kg}$ (increased rates of MAP-S). Cd concentration in the root of lettuce grown on the vertisol was in the range of $1.6 \mathrm{mg} / \mathrm{kg}$ (control) to $53.1 \mathrm{mg} / \mathrm{kg}$ (increased rates of MAP-S). Results show that increased rates of $C d$ incorporated into the soil through phosphorus fertilizer led to an increase in $\mathrm{Cd}$ concentration in the lettuce root, on both types of soil. Moreover, the root of lettuce grown on the pseudogley accumulated statistically significantly higher amounts of Cd compared to that on the vertisol, which is associated with the increased $\mathrm{Cd}$ 
Table 3

PERCENTAGE VALUES OF DTPA-Cd IN A TOTAL Cd CONTENT IN SOIL AND TRANSFER FACTOR

\begin{tabular}{|c|c|c|c|}
\hline Type of soil & Fertilizer & \%DTPA-Cd & Transfer factor (TF) \\
\hline \multirow{5}{*}{ Pseudogley } & Control & 14.5 & 5.53 \\
& MAP-S $(15 \mathrm{mg} / \mathrm{kg}$ soil) & 15.1 & 8.74 \\
& MAP-S (30 mg/kg soil) & 16.4 & 9.43 \\
& MAP-R (15 mg/kg soil) & 15.1 & 6.04 \\
& MAP-R (30 mg/kg soil) & 15.7 & 7.54 \\
\hline \multirow{5}{*}{ Vertisol } & Control & 50.9 & 5.66 \\
& MAP-S (15 mg/kg soil) & 47.2 & 9.06 \\
& MAP-S (30 mg/kg soil) & 54.7 & 10.00 \\
& MAP-R (15 mg/kg soil) & 47.2 & 6.04 \\
& MAP-R (30 mg/kg soil) & 50.9 & 8.11 \\
\hline
\end{tabular}

contentin the pseudogleyand the higher mobility of this metal in the acid soil. The same pattern of increase in $\mathrm{Cd}$ concentration was observed in lettuce leaves, with the lowest concentration of $\mathrm{Cd}(0.30 \mathrm{mg} / \mathrm{kg})$ found in the untreated control in the vertisol, and the highest $(1.50 \mathrm{mg} / \mathrm{kg})$ in the pseudogley, at high rates of MAP-S. Cd levels in lettuce leaves exceeded maximum allowable concentrations for vegetable crops (Rulebook on the Amount of Pesticides, Metals, Metalloids and Other Toxic Substances, Chemotherapeutics, Anabolics and Other Substances Found in Food Products, Official Gazette of the FRY, issues 5/92, 11/92 and 32/2002). The results of the present study confirm the findings of [3] and [32] who found that lettuce has a high affinity to accumulate heavy metals, which coupled with its short growing season contributes to increased cadmium levels in edible parts. Another confirmation is that cadmium is a highly mobile element readily absorbed and translocated to aboveground parts by the plant. Also, a direct dependence between Cd level in the root system zone and that in the plant was confirmed. There are different mechanisms that explain the ability of the root to accumulate increased amounts of $\mathrm{Cd}$ and thus reduce its translocation to aboveground parts, including anatomical, biological and physiological factors.

Cadmium ions are uptaken from the soil through root cells, following which they pass through plasma membrane and enter the cell via plant transporters. In tolerant crops, Cd is immobilized in the root cells by the formation of complexes with malate- and oxalate-type organic acids [33]. Immobilization can also occur by binding $\mathrm{Cd}$ to metabolically inactive complexes with proteins containing sulfur and accumulating in the root [34] or by blocking via epidermal cells [35]. The most important mechanism involves capture of cadmium ions in vacuoles and their consequential exclusion from cell sites of cell division and respiration, resulting in reduced translocation

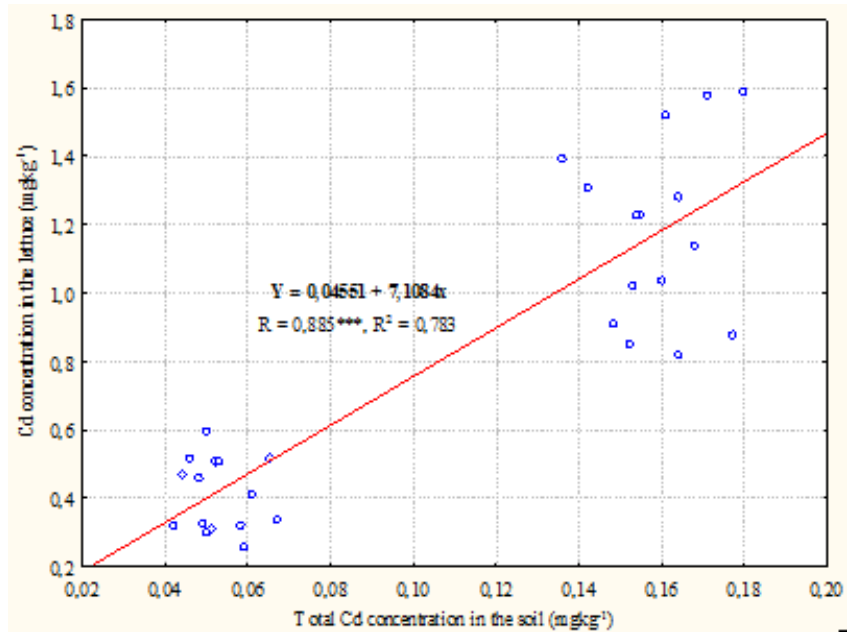

Fig. 3 Relationships between total $\mathrm{Cd}$ concentration in the soil and $\mathrm{Cd}$ concentration in lettuce to aboveground parts [36, 37]. These internal detoxification systems can reduce $\mathrm{Cd}$ translocation, thus making cadmium less toxic to plants.

The correlation analysis of the dependence between total $\mathrm{Cd}$ concentration in the soil and its concentration in lettuce leaves (fig. 3) shows a highly significant positive correlation ( $\mathrm{R}=0.885)$, as previously determined by [11].

No significantcorrelation was observed between available $\mathrm{Cd}$ in the soil and $\mathrm{Cd}$ concentration in lettuce leaves $(\mathrm{R}=-$ 0.082 , fig. 4), which suggests that $C d$ concentration in lettuce is also dependent on other factors (cultivar, plant physiology).

Nevertheless, potential human exposure to toxic effects of soil cadmium through the food chain is bestindicated through the transfer factor (TF) which is directly dependenton soil Cd concentration. In this study, the values of the transfer factor significantly differed between the tested soils (table 3 ) and showed that the uptake of $\mathrm{Cd}$ from the pseudogley soil was much higher than from the vertisol. This is a very important indicator showing a lower risk of $\mathrm{Cd}$ uptake by lettuce grown on the vertisol, which reduces the potential risk of contamination of edible lettuce parts. When growing lettuce in uncontaminated soils, [32] obtained a TF value higher than 0.5 , which is considered by [38] to pose a risk of metal contamination of plants by anthropogenic activities. These results were confirmed in our study, since although lettuce was grown in an uncontaminated soil, $\mathrm{Cd}$ concentration in the leaves was above allowable levels, TF was high, which confirmed that lettuce is a $\mathrm{Cd}$ hyperaccumulator with a high transfer factor, as also determined by [2].

\section{Lettuce head weight}

Lettuce head weight ranged from 139-201 g (pseudogley) and from 169-292 $\mathrm{g}$ (vertisol), showing a decreasing tendency with increasing $\mathrm{Cd}$ amount

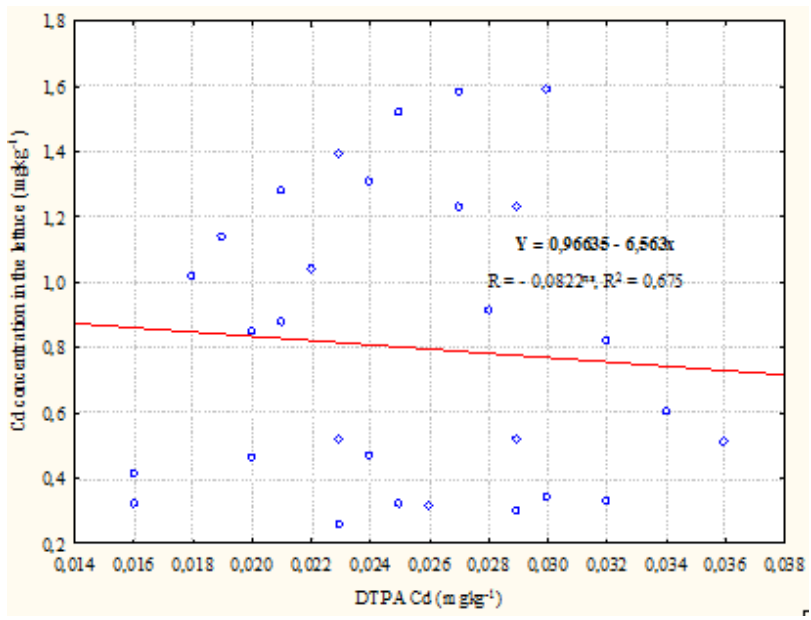

Fig. 4 Relationships between available $\mathrm{Cd}$ concentration in the soil and $\mathrm{Cd}$ concentration in lettuce 
incorporated via MAP to the soil (table 2). [39] used increasing rates of $\mathrm{Cd}$ for lettuce and obtained up to $80 \%$ reduction in lettuce yield. A significantnegative correlation $(R=-0.818$, fig. 5) was determined between $C d$ concentration in lettuce and head weight.

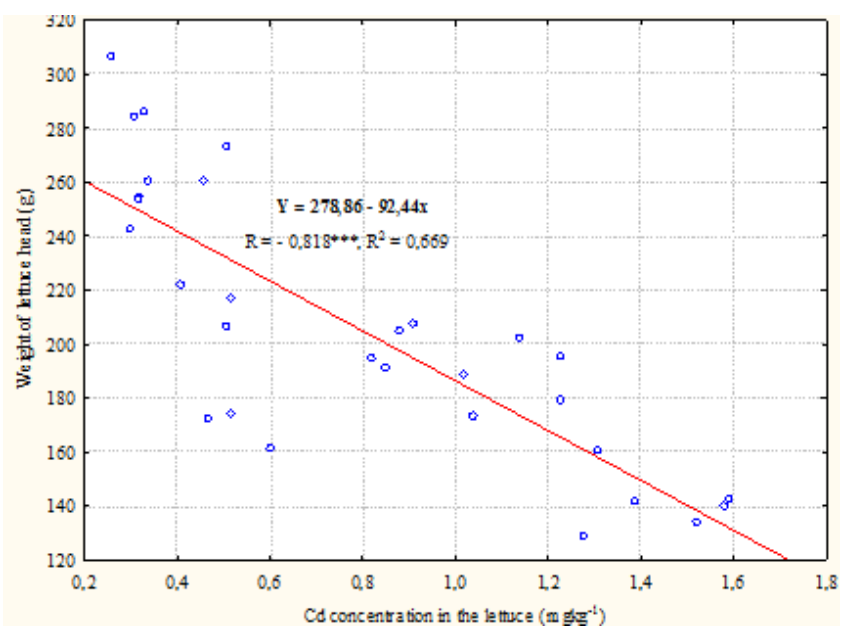

Fig. 5. Relationships between Cd concentration in lettuce and weight of lettuce head

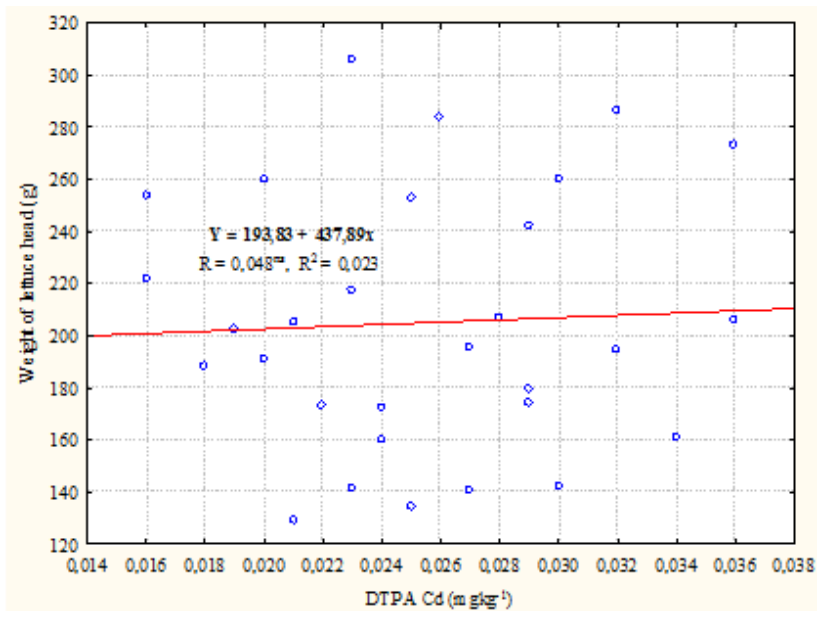

Fig. 6. Relationships between available $\mathrm{Cd}$ concentration in the soil and weight of lettuce head

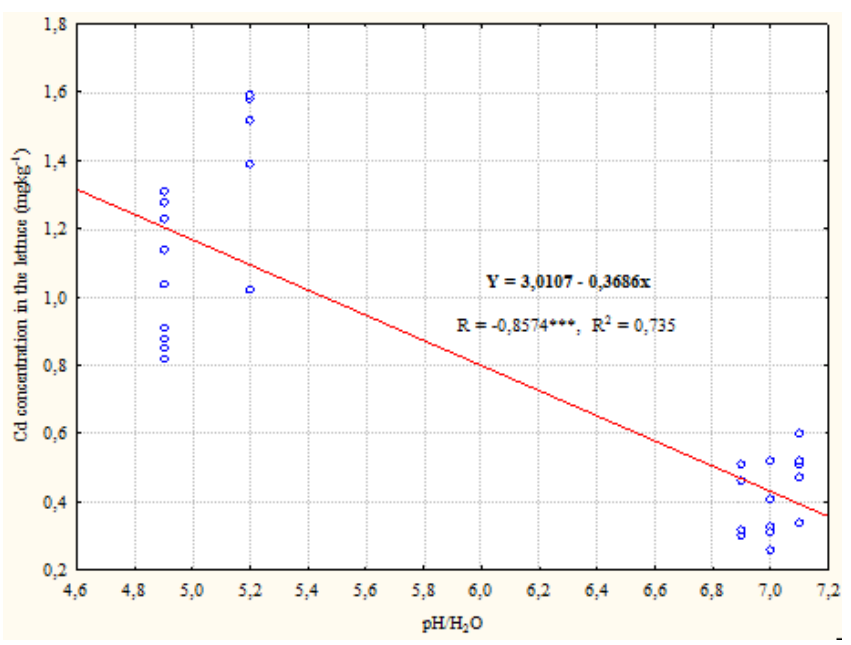

Fig. 7. Relationships between $\mathrm{pH} / \mathrm{H}_{2} \mathrm{O}$ and $\mathrm{Cd}$ concentration in letuce
No correlation was observed between available $\mathrm{Cd}$ in the soil and head weight $(R=0.048$, fig. 6).

These results indicate that $\mathrm{Cd}$ concentration in lettuce is dependent not only on available Cd levels in the soil, but also on $\mathrm{pH}$, as confirmed by the significant negative correlation ( $R_{\text {pHCd leaf }}=-0.857$, fig. 7$)$.

Lettuce yield as dependent on soil available $\mathrm{Cd}$ was evaluated by [3] who found no dependence, while [39] determined a weak negative correlation.

\section{Conclusions}

Total Cd levels in both pseudogley and vertisol soils were below maximum allowable concentrations, which indicates the absence of contamination in these soils. Available $\mathrm{Cd}$ content after lettuce cultivation did not significantly differ between the tested soils, which suggested a higher $\mathrm{Cd}$ uptake by plants grown on the pseudogley than on the vertisol. Cd concentration in lettuce grown on the pseudogley was higher than on the vertisol, with higher amounts of $\mathrm{Cd}$ accumulated in the root than in the leaves. The values of the transfer factor as the most important indicator of potential human exposure to toxic effects of soil cadmium were high, thus suggesting that lettuce is a $\mathrm{Cd}$ hyperaccumulator.

The uptake and accumulation of cadmium by lettuce is mostly affected by soil $\mathrm{pH}$, followed by $\mathrm{Cd}$ availability and a high affinity of lettuce for $\mathrm{Cd}$.

Acknowledgements: This study is part of Project Ref. No. 31059 financially supported by the Ministry of Education and Science of the Republic of Serbia.

\section{References}

1.MEHMOOD, F., RASHID, A., MAHMOOD, T., DAWSON, L., Chemosphere, 90, 2013, p. 1805-1810.

2.CUI, Y.J., ZHU, Y.G., ZHAI, R.H., CHEN, D.Y., HUANG, Y.Z., QIU, Y., LIANG, J.Z., Environ. Int., 30, 2004, p. 785-791.

3.HUANG, B., KUO, S., BEMBENEK, R., Water Air Soil Pollut., 158, 2004, p. 37-51.

4.LAMBERT, R., GRANT, C., SAUVÉ, S., Sci. Total Environ., 378, 2007, p. 293305.

5.BOGDANOVIC, D., UBAVIC, M., CUVARDIC, M., Nutr. Cycl. Agroecosys., 54,1999, p. 49-56

6.JIAO, Y., GRANT, C.A., BAILEY, L.D., J. Sci. Food Agric., 84, 2004, p. 777785.

7.CHEN, W., LI, L., CHANG, A.C., WU, L., KWON, S., BOTTOMS, R., Commun. Soil Sci. Plant Analys., 40, 2009, p. 1124-1137.

8.MULLA, D.J., PAGE, A.L., GANJ E, T.J., J. Environ. Qual., 9, 1980, p. 408-412.

9.RICHARDS, I.R., CLAYTON, C.J., REEVE, A.J.K., J. Agri. Sci., 131, 1998, p. 187-195.

10.MANN, S.S., RATE, A.W., GILKES, R.J. Water Air Soil Pollut., 141, 2002, p. 281-297.

11.MELO, L.C.A., ALLEONI, L.R.F., SWARTJES, F.A., SILVA, E.B., Human Ecol. Risk Assess., 18, 2012, p. 888-901.

12.MacLEAN, A.J ., Can. J. Soil Sci., 56, 1976, p. 129-138.

13.GOLIA, E.E., DIMIRKOU, A., MITSIOS, I.K., Bull. Environ. Contam. Toxicol., 81, 2008, p. 80-84.

14.GUTTORMSEN, G., SINGH, B.R., JENG, A.S., Nutr. Cycl. Agroecosyst, 41,1995, p. 27-31.

15.HE, Q.B., SINGH, B.R., Acta Agriculturae Scand., Sect. B-Soil Plant Sci.,

45, 1995, p. $22-31$.

16.KRISHNAMURTI, G.S.R, HUANG, P.M., KOZAK, L.M., Soil Sci., 164, 1999, p. 888-898.

17.MOUSTAKAS, N.K., AKOUMIANAKIS, K.A., PASSAM, H.C., Commun. Soil Sci. Plant Analys., 32, 2001, p. 1793-1802.

18.SIDHU, V.P.S., KHURANA, M.P.S., Acta Agronomica Hung., 58, 2010, p. 407-417. 
19.NEDJ IMI, B., DAOUD, Y., Flora, 204, 2009, p. 316-324.

20.SANI, H.A., TSAFE, A.I., BAGUDO, B.U., ITODO, A.U., Pak. J . Nutrit, 10, 2011, p. 572-576.

21.MCGRATH, S.P., CUNLIFFE, C.H., J. Sci. Food Agric., 36, 1985, p. 794 798.

22.LINDSAY, W.L., NORVELL, W.A., Soil Sci. Soc. Am. J., 42, 1978, p. 421-428.

23.ALLEN, S.E., GRIMSHAW, H.M., ROWLAND, A.P., Chemical analysis. In Moore PD, Chapman SB, ed. Methods in plant ecology. Blackwell Scientific Publication, Oxford, London, 1986, p. 285.

24.LI, J.T., QIU, J.W., WANG, X.W., ZHONG, Y., LAN, C.Y., SHU, W.S., Environ. Pollut., 14, 2006, p. 159-165.

25.XIAN, X., SHOKOHIFARD, G.I., Water Air Soil Pollut., 45, 1989, p. 265-273.

26.SMITH, S.R., Agricultural Recycling of Sewage Sludge and the Environment, $C A B$ International, Wallingford, 1996.

27.VEGA, F.A., COVELO, E.F., ANDRADE MARCET, M.L.P., Anal. Chim. Acta, 524, 2004, p. 141-150.

28.REMON, E., BOUCHARDON, J.L., CORNIER, B., GUY, B., LECLERC, J.C., FAURE, O., Environ. Pollut., 137, 2005, p. 316-323.

29.ZHUANG, P., MCBRIDE, M.B., XIA, H., LI, N., LI, Z., Sci. Total Environ., 407, 2009, p. 1551-1561.

30.KABATA-PENDIAS, A., PENDIAS, H., Trace elements in soils and plants. $3^{\text {rd }}$ edition, Florida: CRC Press, Boca Ration, 2001.
31.CIESLINSKI, G., NEILSEN, G.H., HOGUE, E.J ., Plant Soil, 180, 1996, p. 267-276.

32.IBRAHIM, A.K., YAKUBU, H., ASKIRA, M.S., American-Eurasian J. Agric. Environ. Sci., 14, 2014, p. 502-508.

33.LUTTS, S., LEFEVRE, I., DELPEREE, C., KIVITS, S., DECHAMPS, C., ROBLEDO, A., CORREAL, E., J. Environ. Qual., 33, 2004, p. 1271-1279. 34.BAKER, A.J.M., EWART, K., HENDRY, G.A.F., THORPE, P.C., W ALKER, P.L., The evolutionary basis of cadmium tolerance in higher plants. In Proceedings 4th International Conference Environmental Contamination, Barcelona. Ed.J Barcelo. CEP consultants, Edinburgh, 1990, p. 23.

35.SOLIS-DOMINGUEZ, F.A., GONZALEZ-CHAVEZ, M.C., CARRILLOGONZALEZ, R., RODRIGUEZ-VAZQUEZ, R., J. Hazard. Mater., 141, 2007, p. 630-636.

36.CHANEY, R.L., MALIK, M., LI, Y.M., BROWN, S.L., BREWER, E.P., ANGLE, J.S., BAKER, A.J.M., Curr. Opinion Biotechnol., 8, 1997, p. 279284.

37.HALL, L., J. Exp. Biology, 53, 2002, p. 1-11.

38.SAJJAD, K., FAROOQ, R., SHAHBAZ, S., KHAN, M.A., SADIQUE, M., World Appl. Sci. J., 6, 2009, 1602-1606.

39.MOYO, D.Z., CHIMBIRA, C., American-Eurasian J. Agric. Environ. Sci., 6,2009 , p. 526-531.

Manuscript received: 6.12 .2018 